\title{
BEHAVIOR OF STOCK RETURN ; EVIDENCE FROM INDONESIA AND MALAYSIA SHARIAH STOCK MARKET
}

\author{
Helma Malini \\ Universitas Tanjungpura, Indonesia
}

\begin{abstract}
This study aims to determine stock return behaviour in Indonesia and Malaysia Shariah stock market. Indonesia and Malaysia are selected based on the countries level of development and geographical factor, since both countries are emerging market with a rapid growth of Shariah stock market not only in term of listed companies but also in term of number of investor. Based on geographical proximity, both countries close to each other and have a strong bilateral relationship which makes their stock market return behaviour influence by many factors. This studies relies on two major time series investigation techniques, namely Economteric Modeling of returns; The Autoregressive model, Assumption of Linearity, Volatility Modeling of GARCH and its extension. The result showed that stock return behavior happening in Indonesia and Malaysia Shariah Stock Market.
\end{abstract}

Keywords : Behavior of Stock Return, Integration, Shariah Stock Market, Volatilities

\section{INTRODUCTION}

The study of stock return behaviour related with information availability and how market prices fully reflect all available information particularly price reaction toward news and events that known as stock return behavior has evolved over the years. The evolution of these studies has contributed to the development of EMH as a theory into many concepts and areas of research interest. Several studies have focused on the role of EMH toward investor behavior and stock return behavior, such as return behavior, seasonal anomaly, equity market integration and stock market volatility.

Several major events hits stock market all over the world, followed with the instability of political and social economic condition forced capital market industry particularly investor to seek stable platform of portfolio (see Trihadmini, 2011). The stability toward financial crisis can be found in the portfolio of investment that offer less shocking volatility toward news and events that happened in one country. Financial crisis that hit the world in 1997 and 2008 has proven a setback for asset gatherers of all kinds in all marketplaces, but it is possible for stock market to derive a long-term benefit because of the capability to serve as an optional investment that is more prone to crisis (Price Water House Coopers, 2009).

*Corresponding author. Email address: helma.malini@ekonomi.untan.ac.id 
AFEBI Islamic Finance and Economic Review (AIFER)

\section{Vol.3 No.2, December 2018}

Table 1. Characteristics of Indonesia and Malaysia Shariah Stock Market

\begin{tabular}{lcccccc}
\hline Country & $\begin{array}{c}\text { S\&P } \\
\text { Category }\end{array}$ & $\begin{array}{c}\text { Capitalization } \\
\text { (End 2019 } \\
\text { USS Million) }\end{array}$ & $\begin{array}{c}\text { Change } \\
\%\end{array}$ & $\begin{array}{c}\text { Value } \\
\text { Traded } \\
\text { (End 2019 } \\
\text { USS } \\
\text { Million) }\end{array}$ & $\begin{array}{c}\text { Turnover } \\
\text { Ratio }\end{array}$ & $\begin{array}{c}\text { Listed } \\
\text { Companies }\end{array}$ \\
\hline Indonesia & Emerging & 172 & -22 & 211.1 & 2.1 & 502 \\
Malaysia & Emerging & 389 & -30 & 2.198 .4 & 6.2 & 925 \\
\hline
\end{tabular}

Source: Standard \& Poor's (2012)

Table 1. describes the characteristics of Indonesia and Malaysia Shariah stock market in terms of capitalization, trading value, turnover ratio and number of listed companies. As emerging markets ${ }^{1}$, Indonesia and Malaysia are in the process of rapid growth in Shariah financial industry. Financial industry growth particularly the growth of capital markets in term or rules, policy, product and socialization. The growth of capital market in Indonesia and Malaysia depends on several factors such as political stability, domestic infrastructure development, currency volatility, seasonal anomaly, integration with other countries and several other correlated and uncorrelated factors. Those factors will eventually create efficient market in Indonesia and Malaysia Shariah stock market.

Stock return behavior is a result from investor behavior; investors tend to response toward news and events in certain pattern that will influence stock price. "Good" or "bad" news often forming "up" or "down" trends in stock market. Stock return behavior is an equilibrium price from supply and demand mechanism in stock exchange, where intrinsic value of stock price describes the present value from cash flow that should be received by investor in the future. Present value of stock price should have represented risk and time of the stock price. When new information is arriving to stock market, investor will adjust by buying or selling the securities, resulting to changing of current price at real value. On the contrary, uninformed investor in stock market, response with a delayed toward information either because the cost of acquiring information is high or information is unreliable. Therefore, the relationship between prices and information flow in stock market may be non-linear.

The level of market efficiency in Indonesia and Malaysia Shariah stock market depends on whether the news incorporates all available information in the stock markets (Ardiansyah and Qoyum, 2011). However, the implementation of trading system in Shariah stock markets makes the dependency level toward macro variable very high. The volatility of conventional stock market will directly influence the level of Shariah

\footnotetext{
1 Emerging stock markets are defined by the Standard and Poor"s Emerging Markets Database (EMDB) to consist of stock markets in the developing countries, i.e. low- and middle-income economies. The Standards and Poor's Emerging Market Database classifies a stock market as 'emerging' if (i) it is located in a low or middle income economy (which, according to the World Bank high income economies, are those with Gross National Income (GNI) greater than $\$ 9,386$ as of 2003); (ii) its investable market capitalization is low relative to its most recent GNI figures, see S\&P (2005 p. 70). This definition effectively puts Indonesia and Malaysia markets in our sample into the category of emerging market economies.
} 


\section{BEHAVIOR OF STOCK RETURN ; EVIDENCE FROM INDONESIA AND MALAYSIA SHARIAH STOCK MARKET}

stock return behaviour. In stock market, company performance is a valuable tool not only to measure the level of profit that will be earned by the investors but also as a measurement for a proper trading mechanism in stock market. While, in Shariah stock market, efficient stock market should describe the real and most current condition of the company that listed in the stock market that eventually will form the real stock price that is based on fairness and transparency.

\section{LITERATURE REVIEW}

Given the volatility of Indonesia and Malaysia Shariah stock market, detected episodes of non-linearity is the result toward market adjustment described in stock price. In stock market, large movement of stock return or asset prices is important to analyze to measure the cause and impact to stock market. Hsieh (1990) noted that there are several news and events that can influence stock price behavior. The 1987 financial crisis is major events that brings extreme bearish or bullish to stock market. Hsieh (1990), also marked the beginning of non-linear behavior, Hsieh stated that large moves in stock market due to chaotic dynamics that will always follow nonlinear dynamics through a process that will never down. Remembering that Indonesia and Malaysia have experience two major crises, the 1997 monetary crisis and subprime mortgage crisis in 2008, study about stock return behavior is very important considering Indonesia and Malaysia stock market uniqueness; large population, behavioral investing culture and volatile investing environment (Michayluk and Neuhauser, 2006; Otchere and Chan, 2003)

Among comprehensive study on stock return behavior, attempts to further reveal stock return behavior in term of stylized facts and news events are still limited, particularly research that focusing on return behavior. Lim and Hinich (2005) study the market behavior of Asian stock market indices using Hinich portmanteau bi-correlation test in conjunction with the windowed testing procedure to examine the cross-temporal universality of non-linear serial dependencies. The result confirms that all Asian stock market indices are appeared to be stable showed by the non-existence of non-linear serial dependencies. As the measurement tools to forecast volatility, non-linearity can capture the dynamics of feature of return; however, this model should be using high frequency data.

Volatility of stock returns behavior toward news and events also describing the availability of public information. The process of measuring stock return behavior toward news and events is by examining time lag between how long information is available to stock price adjustment. In efficient market context, efficient information happened if stock market price change immediately and unbiased upon the arrival of new information (Gaunt, 2000; Lai, et al., 2003 and Lihara et al., 2004) the changing showed that the volatility of price through normal condition, seldom lead investor to earn abnormal profit (Meidawati and Harimawan, 2004). Several news and events are considered to have significant influence, particularly to stock return behavior. Other than financial information, news and events in politics, economy and national securities issue will also reflected in stock price. According to Hadi (2006) market price adjustment depends on how rapid and accurate the information delivered to investor. Several factors contribute to the accuracy of information delivered to investor, including time, place and technology.

Choo and Loo (2011) investigates the existence of spillover effect in Malaysia stock market. Specifically, they study the return and volatility spillover effects between 


\section{AFEBI Islamic Finance and Economic Review (AIFER)}

\section{Vol.3 No.2, December 2018}

Bursa Malaysia Composite Index (KLCI) and Bursa Malaysia Main Board Index. Multivariate GARCH model employed in the study and reveal that small stocks that less government intervention and less restricted compared to larger stocks tend to have more loyal investor, less frequent "buying and selling" strategy and difficult to accumulate public fund for business. Thus, small stocks companies are characterizing with volatility in stock price. The result also proved the dominance effect of large stocks in Malaysian market indicates that information is first incorporated into prices of larger stocks before being explicitly embedded into prices of smaller stocks. Hence, these stocks are interrelated and the spillover effect should be taken into consideration during investing in Malaysian market. However, the testing of spillover effect is more precise if using risk premium as a default to measure the volatility and dynamics of stock market price.

\section{RESEARCH METHOD}

\subsection{Data}

Table 2. Selected Countries for Return Behavior Research

\begin{tabular}{ccc}
\hline Country & Indices & $\begin{array}{c}\text { Number of Listed } \\
\text { Companies }\end{array}$ \\
\hline $\begin{array}{c}\text { Indonesia } \\
\text { (ID) }\end{array}$ & Indonesia Shari'ah Compliance \\
(ISC) & 502 \\
$\begin{array}{c}\text { Malaysia } \\
\text { (MY) }\end{array}$ & $\begin{array}{c}\text { Kuala Lumpur Shari'ah } \\
\text { Compliance (KLSI) }\end{array}$ & 925 \\
\hline
\end{tabular}

\subsection{Methodology}

The discussion is channeled towards return behavior in Indonesia stock exchange Shariah Stock Market and Bursa Malaysia Shariah stock market. Previous empirical evidence concentrates on the behavior of individual stock price or stock price index followed a random walk by using standard statistical techniques such as serial correlation tests (Munir et al., 2012; Lim et al., 2007; Cheong, 2007).

\subsection{Econometric Modeling of returns}

\subsubsection{The Autoregressive Model}

The methodology is consisting of; fitting an $\operatorname{AR}(p)$ to the return series and check the whiteness of the residuals, and following a finding of no further residual autocorrelation, continue with subject the residuals of the $\mathrm{AR}(\mathrm{p})$ to a battery of test to ensure that the residuals are independently and identically distributed (ii). If the result fails to explain the behavior of the data and there is evidence against iid, then the process continues with looking beyond the linear model to explain the remaining structure of the series. After the assumption of linearity is fulfilled number of possible ways of modeling a time series increases dramatically, covering such classes as chaotic dynamics. (Mills, 1995).

Let $\Delta \log$ Pt be stock returns: the $\mathrm{AR}(p)$ model is then

$$
\phi_{\mathrm{p}}(\mathrm{L}) \Delta \log \mathrm{P}_{\mathrm{t}}=\varepsilon_{\mathrm{t}}
$$




\section{BEHAVIOR OF STOCK RETURN ; EVIDENCE FROM INDONESIA AND \\ MALAYSIA SHARIAH STOCK MARKET}

Where the AR polynomial in $\mathrm{L}$ of order $\rho$ is

$$
\phi_{\mathrm{p}}(\mathrm{L})=1-\phi_{1} \mathrm{~L}-\ldots-\phi_{\mathrm{p}} \mathrm{L}^{\mathrm{p}}
$$

And $\varepsilon t$ satisfies the white noise properties

$$
\mathrm{E}\left[\varepsilon_{1}\right]=0, \mathrm{E}\left[\varepsilon_{1}^{2}\right]=\sigma^{2} \text { and } \mathrm{E}\left[\varepsilon_{\mathrm{t}} \varepsilon_{\mathrm{n}}\right]=0 \forall \mathrm{s} \neq \mathrm{t}
$$

\subsubsection{Testing the Assumption of linearity}

Interest toward non-linearity and chaotic processes increased after a large movement of stock price because of severe crisis and stock market crash (Hsieh, 1990). The indication of large movement in stock market in term of capital has triggered unanticipated decision toward news and events particularly news and events with a huge shock and impact to stock market. As a form to challenging EMH and forecasting stock price movements, chaos and non-linearity observed the chaotic toward a large movement of stock price due to response of "bad or good" news. However, the assumption of non-linearity is limited in financial time series, (particularly in term of autocorrelation-based procedures in testing the weak-form EMH).

\subsubsection{Volatility Modeling}

Modeling and forecasting stock return volatility is central to modern finance because risk volatility increased due to market uncertainty and the attempt from market participant to manage asset pricing, asset allocation and risk management. Two approaches generally used are the GARCH and stochastic volatility (SV) models. In their standard forms, the ensuing volatility processes are stationary and weakly dependent with autocorrelations that decrease exponentially (Lu and Perron, 2009). Arguably, volatility, as measured by standard deviation or variance of returns where there is a dispersion of returns for a given security or market index.

\subsubsection{Wild bootstrapped automatic variance ratio (WBAVR) test}

Let $Y t$ be an asset return at time $t$, where $t=1,2, \ldots, T$. Choiec (1999) AVR test statistic takes the following form:

$$
V R(k)=1+2 \sum_{i=1}^{T-1} m(i / k) \hat{\rho}(i)
$$

where $\hat{\rho}(i)$ is the sample autocorrelation of order $I$. These estimations follow Choi (1999) and use the quadratic spectral kernel for the weighting function so that

$$
m(x)=\frac{25}{12 \pi^{2} x^{2}}\left[\frac{\sin (6 \pi x / 5)}{6 \pi x / 5}-\cos (6 \pi x / 5)\right]
$$

According to Choi (1999), $V R(k)$ is a consistent estimator for the normalized spectral density for $Y t$ at zero frequency. Under the null hypothesis that $Y t$ is serially uncorrelated, Choi (1999) shows that:

$$
A V R(k)=\sqrt{T / k}[\operatorname{VR}(k)-1] / \sqrt{2} \stackrel{d}{\longrightarrow} N(0,1)
$$




\section{AFEBI Islamic Finance and Economic Review (AIFER)}

\section{Vol.3 No.2, December 2018}

as $k \square \square, T \square \square, T k \square \square$, when $Y t$ is generated from a martingale difference sequence with proper moment conditions. In order to choose the value of lag truncation point (or holding period) $k$ optimally, Choi (1999) adopts a data-dependent method of Andrews (1991) for the spectral density at the zero frequency. The automatic variance ratio test statistic with the optimally chosen lag truncation point is denoted as $A \operatorname{VR}(\hat{k})$.

To complement the $A V R(\hat{k})$ test, the normal critical values are used at 2.576 and -2.576 for $1 \%$ level of significance. This is based on the asymptotic approximation using the limiting distribution given in. However, this approximation can be inadequate in small samples, especially when $Y t$ is subject to conditional heteroscedasticity. Following $\operatorname{Kim}$ (2006), the wild bootstrap for $A V R(\hat{k})$ is conducted in three stages as below:

(i) Form a bootstrap sample of $T$ observations $Y_{t}^{*}=\eta_{t} Y_{t} \quad \square t$ $\square 1, \ldots, T \square \square$ where $\eta_{t} \square$ is a random sequence with ( ) $\square \square E\left(\eta_{t}\right)=0 \square$ and $E\left(\eta_{t}^{2}\right)=1$;

(ii) Calculate $A V R^{*}\left(\hat{k}^{*}\right)$, the AVR statistic obtained from $\left\{Y_{t}^{*}\right\}_{t-1}^{T} ; \square$ and

(iii) Repeat (i) and (ii) $B$ times to form a bootstrap distribution .

$$
\left\{A V R^{*}\left(k^{*} ; j\right)\right\}_{j=1}^{B}
$$

The two-tailed $p$-value of the test is obtained as the proportion of the absolute values of $\left\{A V R^{*}\left(k^{*} ; j\right)\right\}_{j=1}^{B}$ greater than the absolute value of $A V R(\hat{k})$. The $100 \square 1 \square \square 2 \square \square \square \%$ confidence interval for the test can be obtained as the interval $\left[A V R^{*}(x), \quad A V R^{*}(1-x)\right]$, where $A V R^{*}(x)$ represents the $\alpha$ the percentile of $\left\{A V R^{*}\left(k^{*} ; j\right)\right\}_{j=1}^{B}$. If the test statistic $\operatorname{AVR}(\hat{k})$ lies outside this interval, the null hypothesis is rejected at the $\square 1 \square \square 2 \square \square \square \square$ level of significance.

\subsubsection{The GARCH Model and its extension}

For return volatility, particularly type of models for conditional heteroscedasticity, omitted in review article of Fama (1991) are the so-called GARCHM models (Engle et. al, 1987), in which the conditional variance can be used as a predictor for returns.

The mean equation of stock returns can be described as

$$
\begin{aligned}
& \Delta \log \mathrm{P}_{\mathrm{t}}=\omega+\sum \phi_{\mathrm{i}} \Delta \log \mathrm{P}_{\mathrm{t}-\mathrm{i}}+\varepsilon_{\mathrm{t},} \varepsilon_{1} \mid \Omega_{t-1} \sim \operatorname{NID}\left(0, \mathrm{~h}_{\mathrm{t}}\right) \\
& \varepsilon_{\mathrm{t}}=\mathrm{z}_{\mathrm{t}} \sqrt{\mathrm{h}_{\mathrm{t}}}
\end{aligned}
$$

Where, $\mathrm{z}$ is iid with zero mean and unit variance. The conditional variance $[h t]$ is

$$
\begin{aligned}
\mathrm{h}_{\mathrm{t}} & =\varpi+\sum_{\mathrm{i}=1}^{\mathrm{q}} \alpha_{\mathrm{i}} \varepsilon_{\mathrm{t}-1}^{2}+\sum_{\mathrm{i}=1}^{\mathrm{p}} \beta_{\mathrm{i}} \mathrm{h}_{\mathrm{t}-\mathrm{i}} \\
& =\varpi+\alpha(\mathrm{L}) \varepsilon_{\mathrm{t}}^{2}+\beta(\mathrm{L}) \mathrm{h}_{\mathrm{t}}
\end{aligned}
$$




\section{BEHAVIOR OF STOCK RETURN ; EVIDENCE FROM INDONESIA AND MALAYSIA SHARIAH STOCK MARKET}

The $\alpha i$ in modeling the short run persistence of shocks while the $\beta i$ represent long run persistence. The parameters $\alpha(L)=\alpha 1 L+\ldots \alpha q L q$ and $\beta(L)=\beta 1 L+\ldots+\beta p L p$ are equivalent to an ARMA $(P, q)$ if all the roots of $1-\beta(L)$ lie outside the unit circle. The conditional variance must be non-negative. This necessitates the following restrictions on the parameters: $\omega>0, \alpha>0$ and $\beta i \geq 0$.

The condition is:

$$
\sum_{\mathrm{i}=1}^{\mathrm{q}} \alpha_{1}+\sum_{\mathrm{j}=1}^{\mathrm{p}} \beta_{\mathrm{j}}
$$

Imply that GARCH process is weakly stationary since mean, variance, and auto covariance are finite and constant over time. However, this condition is not sufficient for weak stationary in the presence of autocorrelation. When the GARCH process is stationary, the unconditional variance of $\varepsilon^{t}$, is computed as

$$
V\left(\varepsilon_{\mathrm{t}}\right)=\frac{\omega}{\left(1-\sum_{\mathrm{i}=1}^{\mathrm{q}} \alpha_{1} \sum_{\mathrm{j}=1}^{\mathrm{p}} \beta_{\mathrm{j}}\right)}
$$

The standard GARCH often produces evidence that the conditional volatility process is highly persistent and possibly not covariance-stationary, suggesting that a model in which shocks have a permanent effect on volatility might be more appropriate. One limitation of this process, when applied to financial data, is that the GARCH model has short-memory because volatility shocks decay at a fast-geometric rate. Another problem encounter when using GARCH model is that they do not always fully embrace the thick tails property of high frequency financial time series. In other meaning, a way to represent the observed persistence of volatility in the returns is to approximate a unit root. The result is the integrated GARCH (IGARCH) model,

$$
\sum_{\mathrm{i}=1}^{\mathrm{q}} \alpha_{1}+\sum_{\mathrm{j}=1}^{\mathrm{p}} \beta_{\mathrm{j}}=1
$$

In this formulation, shocks to current volatility are highly persistent. This suggests that current information remains important for forecasts of the conditional variance for all horizons (Engle and Bollerslev, 1986, and Bollerslev et al., 1992).

$$
(1-\alpha(\mathrm{L}))(1-\mathrm{L})^{\mathrm{d}} \varepsilon_{\mathrm{t}}^{2}=\omega+(1-\beta(\mathrm{L})) \mathrm{v}_{\mathrm{t}}
$$

With a $(L)$ and, $\beta(L)$ being polynomials of order $q$ and $p$, and $0<\mathrm{d}<1$ is the fractional integration parameter. Defining $V^{t}=\varepsilon^{2}-h^{t}$ and rearranging the IGARCH $(p$, $d, q$ ) model can be expressed as

$$
\mathrm{h}_{\mathrm{t}}=\omega+\beta(\mathrm{L}) \mathrm{h}_{\mathrm{t}}+\left(1-\beta(\mathrm{L})-(1-\alpha(\mathrm{L}))(1-\mathrm{L})^{\mathrm{d}}\right) \varepsilon_{\mathrm{t}}^{2}
$$

The advantage of the FIGARCH is that it parsimoniously decouples the long-run and short-run movements in volatility by adding an additional parameter to GARCH (1, 1) model. The long-run component is captured by the fractional differencing parameter $d$ and the short-run component by the lag polynomials. For the case of $d=0$, the FIGARCH reduces to the standard GARCH model. However, many models of asset 


\section{AFEBI Islamic Finance and Economic Review (AIFER)}

\section{Vol.3 No.2, December 2018}

pricing relate expected returns to some measure of risk (e. g., the Capital Asset Pricing and Arbitrage Pricing Models).

$$
\Delta \log \mathrm{P}_{\mathrm{t}}=\mu+\sum \phi_{\mathrm{i}} \Delta \log \mathrm{P}_{\mathrm{t}-\mathrm{i}}+\delta \sqrt{\mathrm{h}}_{\mathrm{t}}+\varepsilon_{\mathrm{t}}
$$

In Indonesia and Malaysia Shariah stock market, daily data for nominal risk-free returns are not available and therefore empirical testing of the risk premium hypothesis is indirect. The GARCH-M specification provides a convenient measure since it connects conditional volatility and equation which is used as a proxy for the risk premium. Since the GARCH model was developed, a huge number of extensions have been proposed in the literature, resulting from perceived problems with the standard GARCH $(p, q)$. Non-negative constraints under GARCH may be violated. A number of asymmetric GARCH models have been proposed. This research employs the GJRLARCH, due to Glosten et al. (1993), and the Exponential GARCH (EGARCH) model, due to Nelson (1991). The GJR adds a term to the conditional variance equation to account for possible asymmetries. This is expressed as

$$
\mathrm{h}_{\mathrm{t}}=\omega+\sum_{\mathrm{i}=1}^{\mathrm{q}} \alpha_{\mathrm{i}} \varepsilon_{\mathrm{t}-\mathrm{i}}^{2}+\sum_{\mathrm{i}=1}^{\mathrm{P}} \beta_{\mathrm{i}} \mathrm{h}_{t-i}
$$

Where,

$$
\mathrm{I}_{\mathrm{t}-1}=\operatorname{lif} \varepsilon_{\mathrm{t}-1}<0 \quad=0 \text { otherwise }
$$

And $\alpha^{1}, \beta^{1}$, and $\gamma$ are non-negative parameters satisfying conditions similar to are non-negative parameters satisfying conditions similar to those of LARCH. A positive $\mathcal{E}^{\mathrm{t}}-{ }^{1}$, contributes a $\alpha^{1} \mathcal{E}^{\mathrm{t}-12}$ to $h^{t}$ whereas a negative $\mathcal{E}^{\mathrm{t}-{ }^{1}}$ has a larger impact $\left(\alpha^{1}+\gamma\right) \mathcal{E}^{\mathrm{t}}$ 12 when $\gamma>1$ The model uses zero as its threshold to separate the impacts of past shocks, although other threshold values can also be used.

The EGARCH is specified as

$$
\begin{gathered}
\operatorname{In}\left(\mathrm{h}_{\mathrm{t}}\right)=\omega+\sum_{\mathrm{i}=1}^{\mathrm{q}} \alpha_{\mathrm{i}} g\left(\mathrm{z}_{\mathrm{t}-\mathrm{i}}\right)+\sum_{\mathrm{j}=1}^{\mathrm{p}} \beta_{\mathrm{j}} \ln \left(\mathrm{h}_{\mathrm{t}-\mathrm{j}}\right) \\
\text { Where } \\
\left.\mathrm{g}\left(\mathrm{z}_{\mathrm{t}}\right)=\theta \mathrm{z}_{\mathrm{t}}+\gamma|| \mathrm{z}_{\mathrm{t}}|-\mathrm{E}| \mathrm{z}_{\mathrm{t}} \mid\right] \mathrm{z}_{\mathrm{t}}=\varepsilon_{\mathrm{t}} / \sqrt{\mathrm{h}_{\mathrm{t}}}
\end{gathered}
$$

The coefficient of the second term in $\mathrm{g}\left(\mathrm{Z}^{\mathrm{t}}\right)$ is set to be $1(\gamma=1)$ in the formulation. Note that $\mathrm{E}\left|Z^{t}\right|=(2 / \pi) \frac{1 / 2}{2}$ if $\mathrm{Z}^{\mathrm{t}^{\sim}} N(0,1)$. The function $\mathrm{g}\left(\mathrm{Z}^{\mathrm{t}}\right)$ is linear in $Z^{t}$ with slope coefficient $\Theta+1$ if $Z^{t}$ is positive and $\Theta-1$ if $Z^{t}$ is negative. Suppose $\Theta=$ 0 . Large innovations increase the conditional variance if $\left|Z^{t}\right|-\mathrm{E}|Z t|>0$ and decrease the conditional variance if $\left|Z^{t}\right|-\mathrm{E}\left|Z^{t}\right|<0$. Suppose that $\Theta<1$. The innovation in variance, $g\left(Z^{t}\right)$, is positive if the innovations $Z^{t}$ are less than $(2 / \pi) 1 / 2 /(\theta$ $-1)$. Therefore, negative innovations in return cause the innovations to the conditional variance to be positive if $\theta$ is much less than 1 . 


\section{BEHAVIOR OF STOCK RETURN ; EVIDENCE FROM INDONESIA AND \\ MALAYSIA SHARIAH STOCK MARKET}

\subsubsection{Parameter Estimation of GARCH Models}

To predict volatility of time series, the GARCH model has to be fitted into time series in question. The family of GARCH models is estimated by the maximum likelihood (ML) method. The ML method is the procedure of finding the most likely values of the parameters given the actual data. The log likelihood function is computed from the product of all conditional densities of the prediction errors. If we assume conditional normality, the likelihood function is specified as

$$
\mathrm{L}(\theta)=-\frac{\mathrm{T}}{2} \operatorname{In}(2 \pi)-\frac{1}{2} \sum_{\mathrm{t}=1}^{\mathrm{T}}\left(\operatorname{In}\left(\mathrm{h}_{\mathrm{t}}\right)\right)+\frac{\varepsilon_{\mathrm{t}}^{2}}{\mathrm{~h}_{\mathrm{t}}}
$$

Where

$$
\varepsilon_{1}=\Delta \log \mathrm{P}_{\mathrm{t}}-\sum \phi_{1} \Delta \log \mathrm{P}_{\mathrm{t}=\mathrm{i}}
$$

And $h^{t}$ is the conditional variance. When the $\operatorname{GARCH}(p, q)-\mathrm{M}$ model is estimated,

$$
\varepsilon_{1}=\Delta \log \mathrm{P}_{\mathrm{t}}-\sum \phi_{1} \Delta \log \mathrm{P}_{\mathrm{t}=\mathrm{i}}-\delta \sqrt{\mathrm{h}_{\mathrm{t}}}
$$

It is, however, very unlikely that stock return in emerging market such as Indonesia and Malaysia to follow normal distribution because of the market is undergoing constant changes and makes the market difficult to adjust historical information to create correlation between events and returns. Moreover, since the background of this study is Shariah stock market in Indonesia and Malaysia that requires stability in term of stock price toward volatility in news and events.

$$
\begin{aligned}
\mathrm{L}(\theta)=\frac{\mathrm{T}}{2}[\operatorname{In}(\mathrm{v}-2) & \left.+2 \ln \left[\pi^{1 / 2} \Gamma\left(\frac{\mathrm{v}}{2}\right)\right]-\operatorname{In} \Gamma\left(\frac{\mathrm{v}+1}{2}\right)\right] \\
& -\frac{1}{2} \sum_{\mathrm{t}=1}^{\mathrm{T}}\left[\operatorname{In}\left(\mathrm{h}_{\mathrm{t}}\right)+(\mathrm{v}+1) \operatorname{In}\left(1+\frac{\varepsilon_{\mathrm{t}}^{2}}{\mathrm{~h}_{\mathrm{t}}(\mathrm{v}-2)}\right)\right]
\end{aligned}
$$

Where $\Gamma(\bullet)$ is the gamma function and $\mathrm{v}$ is the degrees of freedom $(\mathrm{v}>2)$. Under a conditional $\mathrm{t}$-distribution, the additional parameter $1 / \mathrm{v}$ is estimated. The $\log$ likelihood function for the conditional $\mathrm{t}$-distribution converges to the log likelihood function of the conditional normal GARCH model as $1 / \mathrm{v} \rightarrow 0$.

\section{RESULT AND DISCUSSION}

Descriptive statistics are given in table 4.1. From the table, several conclusions can be made. First, total number of observations used in this research is 11 years. The daily average return of Malaysia is higher than Indonesia, showed by the value of mean in Kuala Lumpur around 3 percent while in Indonesia is 1 percent. The most volatile Shariah stock market is Malaysia, showed by the value of standard deviation. Highest 


\section{AFEBI Islamic Finance and Economic Review (AIFER)}

\section{Vol.3 No.2, December 2018}

volatility in Malaysia Shariah stock market refers to the vulnerability towards the changing of their stock market environment. While, Indonesia Shariah stock market showed stability during period of observation. The volatility of stock price in Indonesia and Malaysia Shariah stock market showed that stock price volatility depends on several factors including the availability of information to investor, whether the information is in form of past, public or private information.

Table 3. Descriptive Statistic (Logarithmic Returns) of Indonesia and Malaysia Shariah Stock Market

\begin{tabular}{ccc}
\hline Item & Indonesia & Malaysia \\
Mean & 0.1411 & 0.3872 \\
Median & 0.4500 & 0.3700 \\
Maximum & 0.4900 & 0.4800 \\
Minimum & 0.0956 & 0.3300 \\
Standard Deviation & 0.0426 & 0.9224 \\
Skewness & 0.0206 & 0.8608 \\
Kurtosis & 2.3836 & 3.0325 \\
Jarque-Bera & 0.1898 & 1.3592 \\
Probability & 0.9094 & 0.5068 \\
Sum & 1552 & 2626 \\
Sum Sq. Dev. & 0.9871 & 0.0182 \\
Observations & 11 & 11 \\
\hline
\end{tabular}

Notes: number of observation is 11 years while data for statistical process is using daily data.

The results in table 4.1 also strengthen to the common belief that higher risk will lead to higher return. Malaysia Shariah stock market based on the standard deviation offering highest volatility but also offering highest daily average return compared to the Indonesia Shariah stock market. The distributional properties of returns appear to show extreme observations. The highest kurtosis in the sample occurs in Malaysia Shariah stock market, and Indonesia Shariah stock market having the lowest. However, if kurtosis in one country exceeds the threshold of 3 , implying that the returns have fatter tails than would be expected from a normally distributed variable. With the exception of Indonesia, all the return series are positively skewed. The Jarque-Bera (JB) is 0.189865 for Indonesia and 1.359244 for Malaysia. 


\section{BEHAVIOR OF STOCK RETURN ; EVIDENCE FROM INDONESIA AND \\ MALAYSIA SHARIAH STOCK MARKET}

\subsection{Preliminary Evidence: AR (p) Model}

An AR $(p)$ model was fitted to the returns of Indonesia and Malaysia Shariah stock market to ensure the pre-whiten residual before testing the evidence of non-linearity. Stock market returns are of the modeled as autoregressive time series with random disturbances having conditional heteroscedastic variances, particularly with GARCH type processes. This research is analyzing two data sets of stock prices, fitting an AR $(p)$ model to the series by ordinary least squares regression yielded the results in Table 3.

Table 4. AR (p) Pre-Whitening MODEL (Indonesia and Malaysia Shariah Stock Market)

\begin{tabular}{|c|c|c|}
\hline & Indonesia & Malaysia \\
\hline$\mu$ & $0.191(42)$ & $0.197(68)$ \\
\hline$\phi 1$ & 0.1033 .756 & 0.835553 \\
\hline$\phi 2$ & 0.0000 & 0.053332 \\
\hline$\phi 3$ & 0.1809 .230 & 0.550776 \\
\hline$\phi 4$ & 0.0542380 & 0.055294 \\
\hline$\phi 5$ & 0.19199 & 0.592207 \\
\hline$\phi 7$ & 0.10366 & 0.522513 \\
\hline$\phi 8$ & 0.039207 & 0.05294 \\
\hline$\phi 10$ & 0.014153 & 0.056241 \\
\hline$D W$ & 2.017035 & 1.765597 \\
\hline B.G(5) & $0.73[0.424]$ & $0.25[1.641]$ \\
\hline$L B Q(12)$ & $2.13[0.621]$ & $3.16[0.531]$ \\
\hline$L B Q(24)$ & $12.121[0.761]$ & $12.033[0.261]$ \\
\hline
\end{tabular}

Notes: $*, * *$, and $* * *$ indicates significance at $10 \%, 5 \%$ and $1 \%$ levels respectively, $\mu$ is the constant. $\phi$ indicate the AR coefficients. B.G. is Breusch-Godfrey test for higher order serial correlation; D. W is the Durbin-Watson test for autocorrelation; LBQ (12), LBQ (24) indicates the Ljung-Box statistics for 12 and 24- lags respectively. Test statistics are shown in ( ) while p-values are shown in [ ].

Both Shariah stock market in Indonesia and Malaysia following the low order autoregressive with general assumption that Indonesia is follows the AR(1) process 


\section{AFEBI Islamic Finance and Economic Review (AIFER)}

\section{Vol.3 No.2, December 2018}

while Malaysia is follows the $\operatorname{AR}(2)$ process. Having fitted an AR ( $p$ ) model, it is now necessary to examine an adequate and useful functional form for the data generating process. To eliminate of spurious autocorrelation, $\operatorname{AR}(p)$ also has a function to investigate and examine whether the nonlinear dynamics are localized in time. In the case of stock price in Indonesia and Malaysia, the dynamics volatility of the stock price can be minimized by taking an integrated screening process to the listed company, as precautions steps toward volatility. In order to examine further the properties of the data, the research employed the nonlinear diagnostic tests outlined in Table 5.A and 5.B.

Table 5.A. Nonlinearity Test on AR ( $p)$ Residuals

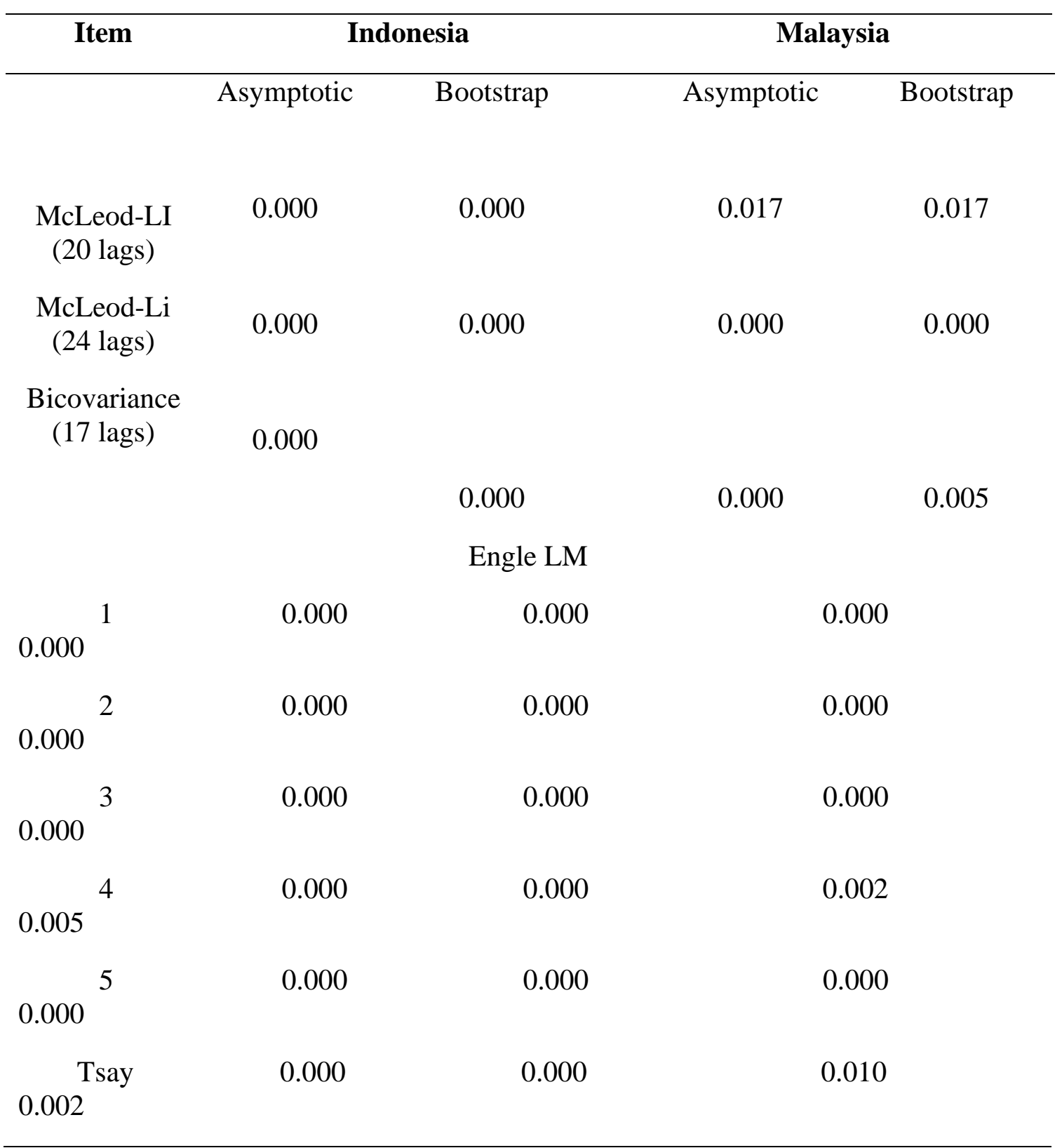




\section{BEHAVIOR OF STOCK RETURN ; EVIDENCE FROM INDONESIA AND}

MALAYSIA SHARIAH STOCK MARKET

Table 5.B. BDS Test on AR ( $p$ ) Residuals

\begin{tabular}{|c|c|c|c|c|c|c|}
\hline Dimension & & Indonesi & & & Malaysia & \\
\hline & $\mathrm{EPS}=1$ & $\mathrm{EPS}=2$ & $\mathrm{EPS}=5$ & $\mathrm{EPS}=1$ & $\mathrm{EPS}=2$ & $\mathrm{EPS}=5$ \\
\hline & & & Bootstr & & & \\
\hline 2 & 0.000 & 0.000 & 0.000 & 0.000 & 0.000 & 0.000 \\
\hline 3 & 0.000 & 0.000 & 0.000 & 0.000 & 0.000 & 0.000 \\
\hline 4 & 0.000 & 0.000 & 0.000 & 0.000 & 0.000 & 0.000 \\
\hline & & & Asymp & & & \\
\hline 2 & 0.000 & 0.000 & 0.000 & 0.000 & 0.000 & 0.000 \\
\hline 3 & 0.000 & 0.000 & 0.000 & 0.000 & 0.000 & 0.000 \\
\hline 4 & 0.000 & 0.000 & 0.000 & 0.000 & 0.000 & 0.000 \\
\hline
\end{tabular}

Notes: only p-values are reported under the null hypothesis that the time series is a serially iid process. All calculations are done using the non-linear toolkit by Patterson and Ashley (2000).

The existence of linearity in Indonesia and Malaysia Shariah stock market shows that both stock market open for gaining abnormal return, where in the case of market efficiency, gaining abnormal return is prohibited. Moreover, the existence of linearity in stock market also showed the capability of predicts returns and lead to inefficiency in stock market showed by the value of EPS and Bootstrap modeling process in the table. Since information are not available to all investor. The existence or non-existence of nonlinearity in stock market is crucial not only for stock market but also for investor to determine appropriate strategy for trading. For example, if stock market follows nonlinear behavior, it is not profitable for investor to use linearity based on trading strategies. Furthermore, nonlinearity test are very effective tools that can be used as diagnostic test to explore and understand the nature of the underlying dynamics in stock returns.

A strong evidence of non-linearity in Indonesia and Malaysia Shariah stock market shows that EMH is rejected in both stock market. The result implies that stock market in Indonesia and Malaysia are potential for testing the predictability in stock returns (Antoniu et al., 1997; Petterson and Ashley, 2000) and the conventional linear statistical test based on autocorrelation coefficients and run test are not capable of capturing nonlinearity, as they are designed to uncover linear pattern in the data.

\subsection{Results of Fitting GARCH Models}

The objective of this section is to deal with the practical issue of estimation and to conclude the distinction between estimation of the two models that used for Indonesia and Malaysia Shariah stock market. 
Table 6. Results of Fitting GARCH Models

\begin{tabular}{|c|c|c|c|c|c|c|}
\hline \multirow[t]{2}{*}{ Item } & \multicolumn{3}{|c|}{ Indonesia } & \multicolumn{3}{|c|}{ Malaysia } \\
\hline & GARCH & $\begin{array}{c}\text { EGARCH- } \\
\text { M }\end{array}$ & $\begin{array}{c}\text { GJR- } \\
\text { GARCH } \\
-\mathrm{M}\end{array}$ & GARCH & $\begin{array}{l}\text { EGARCH- } \\
\mathrm{M}\end{array}$ & $\begin{array}{c}\text { GJR- } \\
\text { GARCH- } \\
\text { M }\end{array}$ \\
\hline$\mu$ & $\begin{array}{c}0.064(1.22 \\
2)\end{array}$ & $0.024 *$ & $\begin{array}{c}0.02(0.3 \\
3)\end{array}$ & $\begin{array}{c}0.325 * *(6 \\
67)\end{array}$ & $\begin{array}{c}0.012(0.01 \\
/ 0\end{array}$ & $0.61(0.05)$ \\
\hline$\delta$ & & $0.022 *$ & $\begin{array}{c}0.71(0.6 \\
6)\end{array}$ & $\begin{array}{c}0.22475 .87 \\
)\end{array}$ & $\begin{array}{c}0.022(0.01 \\
/ 0\end{array}$ & $\begin{array}{c}0.041(0.07 \\
)\end{array}$ \\
\hline$\phi^{1}$ & $\begin{array}{c}0.1202(4.4 \\
04)\end{array}$ & $\begin{array}{c}0.1125(1.3 \\
65)\end{array}$ & $\begin{array}{l}0.657(3 . \\
21)\end{array}$ & $\begin{array}{c}0.1701(4.4 \\
05)\end{array}$ & $\begin{array}{c}0.8761(1.1 \\
65)\end{array}$ & $\begin{array}{c}0.221(0.21 \\
)\end{array}$ \\
\hline$\phi^{2}$ & & & & & & \\
\hline$\phi^{3}$ & & & & & & \\
\hline$\omega$ & $\begin{array}{c}0.064 * *(0 \\
61)\end{array}$ & $\begin{array}{c}0.283(6.23 \\
1)\end{array}$ & 0.0344 & 0.05281 & 0.87645 & $0.876^{* *}$ \\
\hline$\alpha^{1}$ & $0.327 * * *$ & $0.211 * * *$ & $0.681 * * *$ & $0.897 * * *$ & $0.545^{* * *}$ & 0.7865 \\
\hline$\beta^{1}$ & $0.7801 *$ & 0.42377 & 0.54222 & 0.54907 & $0.6712 * *$ & $0.9873 * *$ \\
\hline$\gamma$ & $0.138(33)$ & $0.271(612)$ & $\begin{array}{c}0.679(55 \\
)\end{array}$ & & $0.872 * * *$ & $0.321 * *$ \\
\hline$A I C$ & 2.215 & 2.654 & 1.239 & 3.765 & 1.873 & 0.243 \\
\hline$S B C$ & 2.068 & 1.682 & 1.765 & 2.943 & 1.376 & 1.543 \\
\hline $\begin{array}{l}L B Q^{2}(1 \\
2)\end{array}$ & 09.712 & 7.281 & 5.763 & 4.869 & 1.879 & 1.543 \\
\hline $\begin{array}{l}L B Q^{2}(2 \\
4)\end{array}$ & 32.285 & 16.421 & 11.074 & $\begin{array}{c}0.654(0.00 \\
0)\end{array}$ & $\begin{array}{c}1.903(0.61 \\
)\end{array}$ & $\begin{array}{c}1.243(000 \\
0)\end{array}$ \\
\hline $\begin{array}{l}A R C H(1 \\
0)\end{array}$ & $\begin{array}{c}0.613(0.21 \\
8)\end{array}$ & $\begin{array}{c}0.641(0.68 \\
5)\end{array}$ & $\begin{array}{c}0.289(87 \\
1)\end{array}$ & $\begin{array}{c}0.453(0.89 \\
6)\end{array}$ & $0.765(876)$ & $\begin{array}{c}0.7811(0.0 \\
00)\end{array}$ \\
\hline$v$ & 1.821 & 1.612 & 1.654 & 3.289 & 3.876 & 1.652 \\
\hline$L L$ & -123.11 & -344.55 & -432.33 & -184.98 & -765.22 & -874.78 \\
\hline$\alpha+\beta$ & 0.18 & 1.48 & 1.75 & 0.67 & 0.78 & 0.29 \\
\hline
\end{tabular}




\section{BEHAVIOR OF STOCK RETURN ; EVIDENCE FROM INDONESIA AND MALAYSIA SHARIAH STOCK MARKET}

Statistics are reported in ( ) while p-values are reported in [ ] beside the calculated coefficient. $\mathrm{N}$ is the scale parameter of the distribution of the error term (ie. the student $\mathrm{t}$-distribution).

The majority of volatility studies in stock market apply the GARCH $(1,1)$, due to large number of parameters to be estimated in Indonesia and Malaysia Shariah stock market, the order of lags cannot be restricted only to the variance model of GARCH (1, 1). The result from the table show that from GARCH model specification capture volatility in Malaysia Shariah stock market, while for Indonesia Shariah stock market the result from GARCH model specification show that the volatility is ranging and cannot provide forecasting tools in the future.

\subsection{Test for Asymmetry}

For risk adverse investor, the volatility of stock market will have triggered them to move their funding from one portfolio to another portfolio, in order to take advantages of gaining benefit from one portfolio volatility, if volatility is highly correlated between portfolios to other portfolios. The existence of volatility in stock market implies that a large stock movement in conventional stock market will have implication to return. However, during financial crisis, stock market showed good performance in terms of volatility, where, volatility that caused by financial crisis do not has significant impact to the listed stocks in stock market (Romli et al. 2012).

Table 7. Asymmetry Test Result

\begin{tabular}{ccc}
\hline & $\begin{array}{c}\text { Indonesia Stock } \\
\text { Exchange } \\
\text { Diagnostic Test } \\
\boldsymbol{\rho} \text {-values }\end{array}$ & $\begin{array}{c}\text { Bursa Malaysia } \\
\boldsymbol{\rho} \text {-values }\end{array}$ \\
Sign Bias & 0.345 & 0.367 \\
Positive Size Bias & 0.227 & 0.336 \\
Negative Size Bias & 0.326 & 0.337 \\
Sign and Size Bias & 0.256 & 0.146 \\
\hline
\end{tabular}

Notes: The estimation using GARCH $(1,1)$ models, for daily ISC and KLSC returns using QMLE algorithm. The existence of the asymmetric volatility response is then checked using the sign bias, the negative size bias, and the positive size bias tests. The diagnostic tests are reported.

To give more clear explanation, three diagnostic tests for volatility models: The Sign Bias Test, the Negative Size Bias Test, and the Positive Size Bias Test. The sign 


\section{AFEBI Islamic Finance and Economic Review (AIFER)}

\section{Vol.3 No.2, December 2018}

bias test shows whether positive and negative innovation affect future volatility differently from the prediction of the model. In the negative size bias test, shows whether larger negative innovations are correlated with large biases in predicted volatility. In the positive size bias test shows whether larger positive innovations are correlated with large biases in predicted volatility. The asymmetry test results indicate that the sign and the size of the unexpected return shock do not influence current volatility differently which contradicts the presumption that there are asymmetric effects in the stock market volatility. Negative size bias and positive size bias test are not significant. The joint test is not also significant. A rejection of the asymmetry test showed that stock market return was response to the positive and negatives shocks on volatility and providing the same impact towards stock return.

These results are response from investor towards volatility that happened in Indonesia and Malaysia. In portfolio that represent strong growth of Shariah stock market in Indonesia and Malaysia, both countries should establish efficient and regulated trading platform, minimizing transaction cost, availability of information that reflected in price. In particular the findings have similarity to the pattern that investor overreacts or under react to good and bad news (Spyrou, 2001).

\section{CONCLUSION}

Stock return behavior in this paper is acknowledging by modeling stock price and return of companies that classified in Indonesia and Malaysia Shariah stock market. After conducting and examining three model analyses, summarization can be made that to reach the stage of return behavior in term of information, Indonesia and Malaysia Shariah stock market obligate to increase flow of information by improving trading system, setting legal transaction framework, and minimizing transaction cost. Lim (2009) stated that several factors can contributes to return volatility in term of information: opening domestic stock market to foreign investors, changes in regulatory framework, adoption of electronic trading systems ${ }^{2}$, and the implementation of price limit system.

The above factors already implement by stock exchange in Indonesia and Malaysia, However, further improvement need to adjust, such as changes in regulatory framework and the implementation of price limit system in order to prevent arbitrage and gambling activities. Indonesia and Malaysia Shariah stock market should also open the market for foreign investor to gain benefit from portfolio diversification, eliminating policy that slowing down the growth of investor and giving incentive in form of tax to stimulate growth of foreign investor. Changes in regulation should implement to stock exchange, eliminating regulation such as broker commission, giving protection to investor, reducing systematic risk and ensuring fair, efficient and transparent condition. Changes in regulatory also can be interpreted that stock market in Indonesia and Malaysia should focusing more on developing trading system in Shariah stock market, meaning that conventional stock market should eliminate the possibility of trading mechanism. By doing so, stock market in both country will reach efficient trading environment in term of information. While, the adopting of electronic trading system to

\footnotetext{
${ }^{2}$ Both stock exchange in Indonesia and Malaysia already implemented electronic trading system. Jakarta Automated Trading System (JATS) for Indonesia Stock Exchange and System on Computerized Order Routing and Execution (SCORE) for Bursa Malaysia.
} 


\section{BEHAVIOR OF STOCK RETURN ; EVIDENCE FROM INDONESIA AND MALAYSIA SHARIAH STOCK MARKET}

ensure fair and transparent trading system that linked directly to investor is to ensure fair and transparent market price followed with the implementation of price limits system to ensure price stability and as action against price speculation from investor.

\section{References}

Andrews, D.W.K. (1991). Heteroskedasticity and autocorrelation consistent covariance matrix estimation, Econometrica, 59(3), 817-858.

Antoniou, A., Ergul, N., \& Holmes, P. (1997). Market Efficiency, thin trading and nonlinear Behaviour: evidence from an emerging Market. European Financial Management, Vol.3, No.2, pp. 175 -190.

Ardiansyah \& Qoyum. (2011). Testing the semi strong form efficiency of Islamic Capital Market with response to information content of dividend announcement A study in Jakarta Islamic Index. MPRA Paper No. 41958, posted 16. October 2012 21:15 UTC.

Bollerslev, T., R.Y. Chou and K.F. Kroner. (1992). ARCH modeling in finance: A review of the theory and empirical Evidence. Journal of Econometrics, 52, S59.

Choi, I. (1999). Testing the random walk hypothesis for real exchange rates. Journal of Applied Econometrics, 14(3), 293-308.

Choo, W. and Loo, S. (2011). Return and volatility spillover between large and small stocks in Bursa Malaysia. International Journal of Business and Social Science Vol. 2 No. 2; February.

Cheong, W.C. (2007). Asymmetry and persistence volatility predictability of Malaysian Stock Market. The ICFAI University Press.

Engle, R.F., D.M. Lilien and Robins, R.P. (1987). Estimating time varying risk premia in the term structure: The ARCH-M Model. Econometrica, 55, 391-407.

Engle, R.F. and T. Bollerslev. (1986). Modeling the persistence of conditional variances. Econometric Reviews, 5, 1-50, 81-87.

Fama, E. F. (1991). Efficient capital markets: II. Journal of Finance, XLVI (5), pp. 1575-1617.

Gaunt, C. (2000). Overreaction in the Australian equity market: 1974-1997, Pacific Basin Finance Journal, 375- 398.

Glosten, L. R., Jagannathan, R. \& Runkle, D. E. (1993). On the relationship between the expected value and volatility of the nominal excess return on stocks.

Journal of Finance, 48(5), pp. 1779-1801. 
Hadi, M, M. (2006). Review of capital market efficiency: some evidence from Jordanian market. International Research Journal of Finance and Economics, 3, 13-27.

Hsieh, D. A. (1990). Chaos and nonlinear Dynamics: Application to financial markets. Journal of Finance, 46, pp. 1839-1877.

Kim, J.H. (2006). Wild bootstrapping variance ratio tests, economics letters, 92(1), 3843.

Lai, M.M., Guru, B.K., \& Fauzias, M.N. (2003). Do Malaysian investors overreact?, Journal of American Academy of Business, 602.

Lihara, Y., Kato, H.K. \& Tokunaga, T. (2004). The winner-loser effect in Japanese stock returns, Japan and the world economy, 471-485.

Lim, K. P., \& Hinich, M. J. (2005). Cross-temporal universality of non-Linear dependencies in Asian stock markets. Economics Bulletin, 7(1), pp. 1-6.

Lim, K.P., Tan, H.B \& Law, S.H., (2007). Returns predictability of Malaysia Bank stocks: evidence and implication. International Journal of Management Studies, 14 (1), 89-108.

Lim. K.P. (2009). An empirical analysis of the weak form efficiency of stock markets. Doctoral thesis, Department of Econometric and Business Statistics Monash University, Australia.

Lu, Y. K. \& Perron P. (2009). Modeling and forecasting stock return volatility using a random level shift model. Department of Economics, Boston University, 270 Bay State Rd., Boston, MA, 02215.

Meidawati N,. \& Harimawan, M. (2004). Pengaruh pemilihan umum legislatif Indonesia tahun 2004 terhadap return saham dan volume perdagangan saham LQ45 di PT. Bursa Efek Indonesia (BEJ), SINERGI Kajian Bisnis dan Manajemen, Vol 7 No. 1, 89-101.

Michayluk, D. \& Neuhauser, K.L. (2006). Investor overreaction during market declines: Evidence from the Asian financial crisis. The Journal of Financial Research, xxix (2), 217-234.

Mills, T. C., and Coutts, J. A., (1995). Calendar effects in the London Stock Exchange FTSE Indices. European Journal of Finance, 1, pp. 79-93.

Munir, Q. Ching, K.S, Furouka, F. \& Mansur, K. (2012). The Efficient market Hypothesis revisited : evidence from the five small open Asian stock markets. The Singapore Economic Review, Vol., 57, No 3. 


\section{BEHAVIOR OF STOCK RETURN ; EVIDENCE FROM INDONESIA AND \\ MALAYSIA SHARIAH STOCK MARKET}

Nelson, D., March. (1991). Conditional Heteroskedasticity in asset Returns: A New Approach, Econometrica, 59, 347-370.

Otchere, I. and Chan, J. (2003). Short-term overreaction in Hong Kong stock market: can a contrarian strategy beat the market?.Journal of Behavioral Finance, 4(3), 157-171.

Patterson, D. M. and Ashley, R. A. (2000). A non-linear time series Workshop. Kluwer Academic, London.

Price Water House Coopers, (2009). Shariah-compliant funds: a whole new world of investment.

Romli, N. Mohammad, A.Z.S., \& Yusuf, M.F.M., (2012). Volatility analysis of FTSE Bursa Malaysia: A study of the problems of Islamic stock market speculation in the period 2007-2010. African Journal of Business Management, 6(29), 84908495 .

Spyrou, (2001). Stock returns and inflation: Evidence from an emerging market, Applied Economics Letter, pages 447-450, 2001.

Trihadmini, N. (2011). Contagion dan spillover effect Pasar Keuangan Global Sebagai Early Warning System. Jurnal Ekonomi dan Pembangunan Indonesia, Vol. 11 No. 2. 